\title{
STRATEGI PENINGKATAN PENJUALAN JASA TERAPI PADA JASA PRIVAT TERAPI WICARA DI CIGADUNG
}

\author{
Efi Fitriani \\ efi_rani@yahoo.co.id
}

SEKOLAH TINGGI ILMU EKONOMI EKUITAS

\begin{abstract}
ABSTRAK
Program pengabdian masyarakat ini bertujuan untuk memberikan pelatihan tentang metode strategi peningkatan penjualan jasa terapi wicara. Target khusus yang ingin dicapai adalah dapat meningkatkan penjualan jasa terapi wicara anak dengan menciptakan merk dagang dan melakukan promosi terhadap jasa terapinya. Metode yang digunakan adalah dengan memberikan pelatihan metode strategi peningkatan penjualan jasa. Dengan adanya pelatihan yang akan diberikan oleh tim, usaha layanan terapi ke rumah-rumah lebih berkembang dengan terjadinya peningkatan jumlah kosumen sekitar 70 persen yang menggunakan jasa terapi tersebut. Tentunya pendapatan mitra mengalami peningkatan. Hasil dari kegiatan pengabdian ini antara lain meningkatnya jumlah peralatan terapi yang dimiliki mitra, sudah memiliki brand dan melakukan promosi dengan membuat blog sendiri dan bertambahnya jumlah konsumen sehingga pendapatan mitra mengalami peningkatan. Strategi untuk meningkatkan penjualan jasa terapi yaitu: memilih target pasar, memilih media sosial sebagai sarana promosi, memberikan pelayanan prima, menawarkan pembayaran melalui transfer bank, melakukan promosi yang menarik dengan membuat blog dan membuat program loyalitas.
\end{abstract}

Kata kunci: Industri, Pemasaran, Sale dan Keripik, UMKM.

\section{PENDAHULUAN}

\subsection{Analisis Situasi}

Terapi wicara adalah terapi yang dilakukan bagi seseorang yang mengalami gangguan dalam hal berbicara. Banyak hal yang membuat seseorang akan melakukan terapi wicara antara lain karena mengalami speech delay yaitu di mana keadaan anak yang telat berbicara tidak sesuai dengan perkembangan umurnya.

Untuk melatih anak agar dapat berbicara dengan baik maka dilakukan beberapa stimulasi dengan mengajak anak bermain untuk merangsang perkembangan otaknya sehingga nantinya akan mampu mengucapkan kata-kata dengan baik. Hal ini tentunya memerlukan waktu yang cukup lama untuk memberikan hasil yang maksimal. Bagi orang tua yang mempunyai anak dengan speech delay diperlukan kesabaran dan perhatian yang lebih untuk merangsang perkembangan wicara anaknya.

Pada saat ini banyak usaha yang dijalankan oleh pelaku bisnis untuk memenuhi kebutuhan konsumen khususnya orang tua yang memiliki anak berkebutuhan khusus. Untuk saat ini tidak terlalu banyak tempat terapi yang ada di Bandung sehingga para orang tua harus mencari informasi yang lebih melalui media sosial untuk mendapatkan tempat terapi yang baik. Tempat terapi wicara ada yang dikelola oleh yayasan dan ada juga yang dikelola oleh individu. 
Bagi para orang tua yang bekerja tentunya akan kesulitan dalam mengatur waktu untuk mengantarkan anaknya ke tempat terapi. Sehingga para orang tua yang bekerja lebih senang jika menggunakan jasa privat terapi yang bisa didatangkan ke rumah atau dikenal dengan home visit.

Privat terapi wicara pada anak di daerah Cigadung merupakan usaha yang sudah dilakukan selama dua tahun. Sejak tahun 2017 mitra sebelumnya masih bekerja di salah satu tempat terapi yang ada di Buah Batu Bandung. Selama beberapa tahun terapis ini bekerja di sana dan juga melakukan home visit ke beberapa lokasi. Tentunya jika mengunjungi konsumen ke rumah-rumah mitra mendapat bayaran yang lebih tinggi daripada melakukan terapi di tempat terapi tersebut.

Kemudian seiring dengan jalannya waktu, tempat terapi di mana tempat mitra bekerja, ingin mengembangkan usahanya yang lebih besar lagi, yaitu dengan mendirikan home schooling dan tentunya ini membutuhkan biaya yang besar untuk modal dan menyewa tempat. Sehingga hal ini membawa dampak kurang baik bagi para terapis yang bekerja di sana. Salah satunya adalah pengurangan honor yang dibayarkan kepada terapis. Tentunya ini sangat mempengaruhi kepuasan dari para terapis yang bekerja di sana. Kemudian beberapa orang dari terapis termasuk mitra sendiri mengundurkan diri dengan membuat usaha sendiri dengan melayani terapi ke rumahrumah.

Dengan bermodalkan konsumen lama maka terapis ini menjalankan usahanya secara mandiri selama enam bulan terakhir. Dengan mencoba usahanya sendiri tentunya membutuhkan modal untuk membeli peralatan terapi diantaranya berupa permainan anak-anak edukatif dan lain-lain. Di samping itu terapis ini masih sering mengikuti pelatihan-pelatihan untuk menunjang keterampilannya dalam menangani anak berkebutuhan khusus seperti speech delay, gangguan konsentrasi dan lain-lain. Selama menjalankan usahanya secara mandiri, terapis ini baru mempunyai empat murid yang di asuh ke rumah-rumah. Lokasinya yang dikunjungi cukup jauh, misalnya di Lembang, Pasteur dan lain-lain, sementara tempat tinggal mitra ada di Cigadung.

Usaha ini sebenarnya masih dapat dikembangkan lagi menjadi lebih maju mengingat semakin lama jumlah anak berkebutuhan khusus semakin bertambah. Banyak orang tua yang bekerja yang tidak sempat mengantarkan anaknya untuk terapi wicara ke tempat terapi. Para orang tua lebih memilih menggunakan jasa privat terapi wicara yang didatangkan ke rumah. Hal ini terkadang sulit bagi orang tua yang mempunyai anak berkebutuhan khusus untuk mene-mukan terapi wicara yang tepat.

Adapun dalam hal promosi, privat terapi wicara belum pernah melakukan promosi terhadap jasa terapisnya. Privat terapi wicara ini belum memiliki iklan papan nama yang memadai untuk menandai tempat penjualan jasa terapinya.

Privat terapi wicara ini juga belum pernah membuat brosur untuk disebarkan kepada masyarakat apalagi promosi di media. Hal ini disebabkan karena mitra belum mempunyai brand (merek dagang) untuk jasanya. Promosi adalah kegiatan yang dilakukan perusahaan untuk mengkomunikasikan manfaat produk dan alat untuk mempengaruhi konsumen dalam kegiatan pembelian atau penggunaan jasa sesuai dengan kebutuhan (Lupiyoadi, 2013:92).

Menurut Kotler \& Keller (2012), Merk memiliki manfaat bagi produsennya, diantaranya sebagai berikut :

1. Memudahkan perusahaan dalam menangani produk, terutama bila terjadi masalah akan lebih mudah untuk menulusurinya.

2. Membantu dalam mengatur persediaan dan laporan keuangan, ketika produk sudah ada namanya tentu akan mudah diidentifikasi, termasuk dalam penjualan sampai dengan laporan keuangan.

3. Merek juga akan membantu memberikan perlindungan hukum 
untuk fitur atau aspek unik dari sebuah produk.

4. Brand name dapat dilindungi melalui merek dagang yang terdaftar, proses produksi dapat dilindungi melalui hak paten, kemasaran dapat dilindungi melalui hak cipta dan dasain-desain.

5. Hak atas kekayaan intelektual menjamin perusahaan dapat dengan aman menanam modal dalam brand dan memperoleh keuntungan atas semua aktivitas yang berharga.

Diketahui bahwa murid yang selama ini diasuh oleh mitra hanya mempertahankan konsumen lama, yaitu berjumlah empat orang. Mitra belum mampu memasarkan secara mandiri terhadap penjualan jasa terapis yang dilakukannya. Terbatasnya peralatan yang dimiliki membuat terapis ini enggan untuk memasarkan jasanya ke media sosial. Hal ini akan mempengaruhi kelancaran terapi jika anak yang menjadi calon konsumennya mempunyai masalah yang berbeda-beda. Saat ini mitra belum mempunyai peralatan terapis yang memadai. Dengan adanya peralatan terapis yang lengkap, diharapkan mitra dapat memajukan usahanya untuk membantu para anak berkebutuhan khusus yang semakin lama semakin bertambah jumlahnya. Karena muridnya masih berjumlah empat orang maka dalam hal pendapatan yang diterima oleh mitra masih tergolong kecil.

Dalam hal menentukan tarif home visit disesuaikan dengan lokasi rumah yang akan dituju. Biaya untuk satu kali pertemuan sebesar Rp 100.000,00 ditambah uang transport sebesar Rp 20.000,00. Biasanya untuk satu kali home visit biayanya sebesar Rp 120.000,00 dan akan dibayarkan dalam waktu satu bulan. Para orang tua menggunakan jasa terapi home visit seminggu dua kali sehingga dalam satu bulan terhitung delapan kali pertemuan. Jadi rata-rata pendapatan yang diterima oleh mitra per satu anak sebesar Rp. 960.000,00. Sedangkan jumlah anak yang melakukan terapi home visit baru berjumlah 4 orang. Ini berarti bahwa mitra mempunyai penghasilan per bulannya sebesar Rp 3.840.000, 00 .

Dalam waktu dekat mitra berencana membentuk tempat terapi bersama rekan seprofesinya. Hal ini tentunya membutuhkan modal yang cukup besar untuk menyewa tempat yang akan digunakan untuk terapi wicara serta perlengkapan yang dibutuhkan.

\subsection{Permasalahan Mitra}

Berdasarkan hasil wawancara, ditemukan beberapa masalah yang dihadapi oleh mitra antara lain :

1. Mitra belum mempunyai jumlah murid yang banyak sehingga pendapatan yang diterima masih rendah

2. Mitra belum mempunyai peralatan terapi yang memadai untuk mendukung kelancaran terapi.

3. Mitra belum mempunyai brand (merek dagang) dan belum melakukan promosi terhadap jasa terapinya.

\subsection{Solusi}

Solusi yang ditawarkan dalam masalah ini sebagai berikut :

1. Pelatihan strategi peningkatan penjualan jasa terapi pada jasa privat terapi wicara melalui promosi dan pembuatan blog.

2. Pengadaan peralatan terapi berupa permainan anak-anak yang edukatif dan lain-lain.

3. Menciptakan merek dagang terhadap jasa yang ditawarkan mitra serta melakukan promosi jasa terapinya.

\section{METODE KEGIATAN}

Metode pelaksanaan untuk mendukung realisasi solusi yang ditawarkan sebagai berikut : 
Tabel. 1 Metode Pelaksanaan Pengabdian.

\begin{tabular}{|c|c|}
\hline Tahap dan Metode & Hasil \\
\hline $\begin{array}{lr}\text { 1.Tahap Awal } \\
\text { - Tim } \\
\text { mengidentifikasi } \\
\text { hambatan rran } \\
\text { kendala } & \text { dang } \\
\text { dihadapi oleh } & \text { mitra } \\
\text { - Tim } & \text { akan } \\
\text { memberikan } & \\
\text { pemahaman } & \text { dan } \\
\text { menawarkan } & \text { solusi } \\
\text { mengenai } & \text { strategi } \\
\text { peningkatan } & \\
\text { penjualan } & \text { jasa } \\
\text { terapi wicara } & \text { yang } \\
\text { efektif dan } & \text { efisien } \\
\text { dengan } & \text { cara } \\
\text { membuat } & \text { brand } \\
\text { dan blog } & \text { untuk } \\
\text { melakukan rran } & \\
\text { promosi } & \text { jasa } \\
\text { terapinya } & \end{array}$ & $\begin{array}{l}\text { Pemahaman } \\
\text { persamaan } \\
\text { persepsi dari } \\
\text { pihak yang } \\
\text { terkait, dalam } \\
\text { hal ini tim } \\
\text { dengan mitra. }\end{array}$ \\
\hline $\begin{array}{l}\text { 2.Tahap Pelaksanaan } \\
\text { Pelatihan dan } \\
\text { Konsultasi } \\
\text { mengenai strategi } \\
\text { peningkatan } \\
\text { penjualan jasa terapi } \\
\text { wicara }\end{array}$ & $\begin{array}{l}\text { Arahan Strategi } \\
\text { yang dilakukan } \\
\text { untuk } \\
\text { meningkatkan } \\
\text { penjualan }\end{array}$ \\
\hline $\begin{array}{l}\text { 3.Tahap Akhir } \\
\text { Mendampingi dan } \\
\text { melakukan evaluasi }\end{array}$ & $\begin{array}{l}\text { Pendampingan } \\
\text { sampai mampu } \\
\text { meningkatkan } \\
\text { penjualan jasa } \\
\text { terapi }\end{array}$ \\
\hline
\end{tabular}

\section{HASIL DAN LUARAN}

Dalam melakukan kegiatan ini, pada tahap awal tim mengidentifikasi hambatan atau kendala yang dihadapi mitra, antara lain adalah baru memiliki jumlah murid yang banyak, belum memiliki alat terapi yang variatif, belum mempunyai merk dagang atas jasa terapinya dan belum melakukan promosi atas jasa terapinya.

Kemudian tim mencoba untuk mencari cara untuk mengatasi masalah yang dialami mitra antara lain dengan membeli beberapa variasi peralatan terapi, mengarahkan untuk membuat merek dagang atas jasa terapinya sehingga konsumen menjadi lebih mengetahui terhadap brand jasa terapinya. Untuk mengatasi masalah jumlah murid yang masih sedikit yang berjumlah empat orang, maka tim mengarahkan untuk membuat blog sehingga jasa terapinya lebih dikenal oleh masyarakat.

Dalam melakukan kegiatan ini tentunya ada hambatan yang menyertainya antara lain adalah tim dan mitra tidak bertemu secara tatap muka langsung dikarenakan kondisi pandemi, sehingga arahan-arahan dilakukan melalui media whats apps. Karena mitra hanya sendiri maka tim lebih mudah untuk menginstruksikan usaha-usaha yang perlu dilakukan antara lain adalah dengan mengarahkan untuk membuat brand yang cocok dan menarik terhadap jasa terapinya, membuat blog dan lain-lain.

Setelah kegiatan ini dilakukan maka dua bulan kemudian sudah mulai ada perubahan. Menurut mitra sejak dilakukannya promosi dengan membuat blog terhadap jasa terapinya terdapat sekitar 10 orang yang menghubungi mitra untuk menggunakan jasa terapinya tetapi karena ada beberapa calon konsumen yang tempat tinggalnya terlalu jauh dengan tempat tinggal mitra maka mitra hanya menerima empat orang konsumen untuk dilayani secara home visit. Tentunya hal ini membuat jumlah muridnya menjadi lebih bertambah sehingga membuat penghasilan mitra meningkat daripada sebelumnya.

Tabel. 2 Gambaran Kondisi Mitra Sebelum dan Sesudah dilakukan Kegiatan Pengabdian.

\begin{tabular}{|c|l|l|}
\hline No & \multicolumn{1}{|c|}{$\begin{array}{c}\text { Sebelum } \\
\text { Kegiatan }\end{array}$} & \multicolumn{1}{c|}{$\begin{array}{c}\text { Sesudah } \\
\text { Kegiatan }\end{array}$} \\
\hline 1 & $\begin{array}{l}\text { Memiliki murid } \\
4 \text { orang }\end{array}$ & $\begin{array}{l}\text { Memiliki murid } \\
8 \text { orang }\end{array}$ \\
\hline 2 & $\begin{array}{l}\text { Memiliki } \\
\text { peralatan terapi } \\
\text { yang terbatas }\end{array}$ & $\begin{array}{l}\text { Memiliki } \\
\text { peralatan terapi } \\
\text { lebih variatif }\end{array}$ \\
\hline
\end{tabular}




\begin{tabular}{|c|l|l|}
\hline 3 & $\begin{array}{l}\text { Belum memiliki } \\
\text { merk dagang }\end{array}$ & $\begin{array}{l}\text { Membentuk } \\
\text { merek dagang : } \\
\text { Greenlight kids }\end{array}$ \\
\hline 4 & $\begin{array}{l}\text { Belum } \\
\text { melakukan } \\
\text { promosi }\end{array}$ & $\begin{array}{l}\text { Sudah } \\
\text { melakukan } \\
\text { promosi dengan } \\
\text { membuat blog }\end{array}$ \\
\hline
\end{tabular}

Berikut ada beberapa foto kegiatan yang dilakukan secara daring :

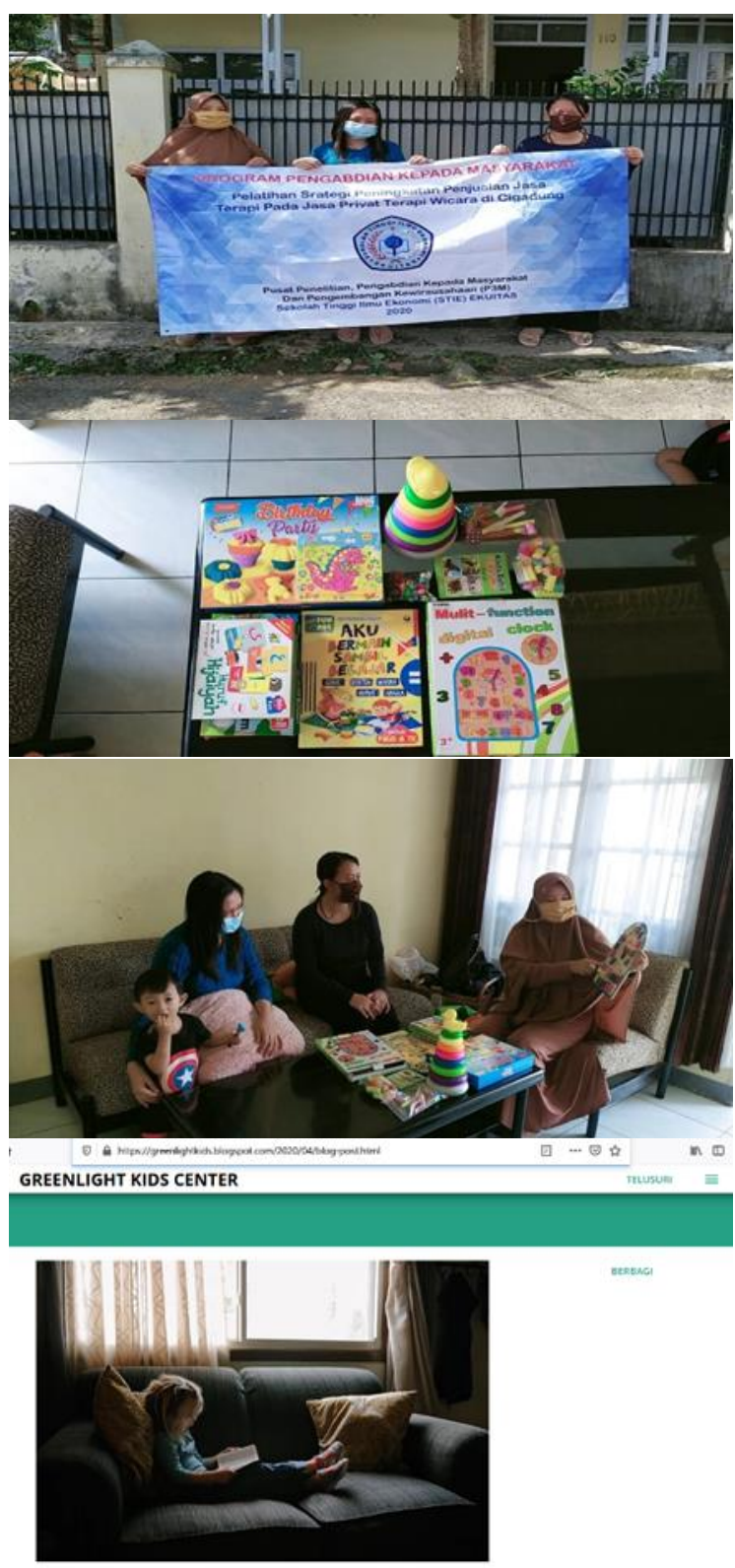

Gambar 1. Home Visit.

Untuk sementara mitra menghentikan kegiatan terapinya. Hal ini terjadi karena para orang tua murid yang meminta untuk kegiatan terapi secara home visit dihentikan dulu mengingat angka covid yang semakin tinggi. Apabila kondisi sudah membaik maka mitra akan kembali meneruskan usaha terapinya. Untuk itu saat ini mitra lebih fokus untuk melanjutkan kuliahnya pada jurusan terapi wicara yang sempat tertunda beberapa tahun yang lalu. Mitra bercita-cita setelah menyelesaikan kuliahnya nanti akan membuat sebuah klinik untuk melayani anak berkebutuhan khusus, khususnya yang mengalami keterlambatan dalam berbicara.

Ada enam cara yang dapat diterapkan untuk memaksimalkan penjualan bisnis layanan profesional :

1. Memilih target pasar

Bagi pebisnis pemula harus bisa menentukan dan memilih target pasar yang menjadi sasaran dari jasa yang ditawarkan. Sehingga jasa yang ditawarkan kepada konsumen akan disambut baik oleh pengguna jasa tersebut.

Dalam hal ini Greenlight kids harus dapat menentukan siapa target pasarnya. Target pasar jasa privat terapi ini yaitu lebih cenderung kepada anak-anak yang berkebutuhan khusus terutama yang mengalami keterlambatan dalam berbicara. Kemudian baru target berikutnya yaitu gangguan lainnya seperti autis, PDD NOS, Gifted, ADHD, ADD dan gangguan dalam konsentrasi belajar. Lebih khusus lagi bagi anak yang berkebutuhan khusus yang memiliki orang tua yang bekerja sehingga tidak bisa mengantarkan anaknya ke tempat terapi.

2. Memilih media sosial sebagai sarana promosi

Pada saat ini media sosial seringkali digunakan orang sebagai media promosi untuk menjual produk maupun jasanya. Banyak media sosial yang dapat digunakan antara lain facebook, instagram dan lain-lain. Semakin banyak follower maka semakin memungkinkan akan mendapatkan konsumen yang menjadi target pasarnya. 
Greenlight kids belum melakukan promosi di media sosial seperti Instagram maupun facebook. Hal ini terjadi karena belum maksimal dalam memenuhi keinginan konsumen dan terkendala dengan lokasi rumah pengguna jasa terapi yang terlalu jauh dari kediaman mitra. Tetapi pada saat ini mitra sudah membuat blog dalam mempromosikan jasa terapinya dengan alamat web sebagai berikut : https:/greenlightkids.blogspot.com/202 0/04/blog-post.html

3. Memberikan pelayanan prima

Dalam hal menjual jasa, pelayanan sangat diperlukan bagi konsumen. Dengan memberikan pelayanan yang baik, konsumen akan menyenangi dalam menggunakan jasa yang ditawarkan sehingga ketika konsumen merasa puas maka dengan sendirinya akan tercipta loyalitas. Jika konsumen sudah loyal maka dengan sendirinya konsumen tersebut ikut mempromosikan produk/jasa kepada orang lain dan tentunya hal ini pasti akan menguntungkan bagi produsen tersebut.

Dalam hal ini Greenlight kids harus dapat melayani konsumen dengan pelayanan yang baik, misalnya walaupun lokasi home visit jauh tetapi tetap bisa melayani dengan baik guna untuk memenuhi permintaan konsumen. Mitra juga harus sabar dalam melayani anak berkebutuhan khusus yang tentunya mempunyai masalah yang berbeda-beda sehingga mereka bisa nyaman dalam menggunakan jasa terapi tersebut.

4. Menawarkan pembayaran melalui transfer bank

Pada saat ini untuk memudahkan konsumen dalam melakukan pembayaran maka pihak produsen harus bisa menawarkan beberapa pilihan pembayaran diantaranya melalui transfer bank, kartu kredit dan lain-lain.

Dalam hal ini untuk menggunakan jasa terapi mungkin kurang cocok dengan menggunakan kartu kredit mengingat jumlah yang harus dibayarkan oleh pengguna jasa terapi setiap bulannya tidak terlalu banyak. Mungkin metode yang paling tepat dalam melakukan pembayaran yaitu dengan transfer bank.

5. Menawarkan promosi yang menarik.

Promosi dilakukan untuk mendapatkan konsumen lebih banyak, sehingga perlu adanya usaha yang dilakukan untuk menarik minat beli konsumen.

Dalam hal ini Greenlight kids juga harus bisa melakukan promosi kepada pengguna jasa terapi, misalnya sebelum melakukan terapi seorang anak akan diobservasi terlebih dahulu untuk menentukan terapi apa yang dibutuhkan, dalam hal ini mungkin mitra tidak memungut biaya untuk observasi. Sehingga akan menarik orang yang akan menggunakan jasa terapi tersebut.

6. Membuat program loyalitas

Program loyalitas dapat dilakukan untuk menjaga hubungan baik dengan kosumen sehingga konsumen akan tetap setia menggunakan produk/jasa yang ditawarkan. Dalam hal ini Greenlight kids belum maksimal dalam melakukan program loyalitas karena masih awal yaitu dengan mengajak para pelanggannya untuk bergabung pada acara parenting anak berkebutuhan khusus.

Sebelum dilakukan pengabdian kepada mitra, ada beberapa hal yang belum dimiliki yaitu belum mempunyai perlengkapan yang memadai untuk media terapi, belum memiliki brand dan belum melakukan promosi di media sosial. Setelah dilakukan pengabdian kepada mitra, setidaknya sudah ada perubahan yang terjadi diantaranya jumlah peralatan terapi menjadi lebih variatif, sudah punya brand dan sudah melakukan promosi dengan membuat blog serta bertambahnya jumlah konsumen sehingga pendapatan mitra mengalami peningkatan. 


\section{KESIMPULAN}

Setelah dilakukan pengabdian kepada mitra, perubahan yang terjadi diantaranya jumlah peralatan terapi menjadi lebih variatif, sudah adanya merk dagang yaitu Greenlight kids dan sudah melakukan promosi dengan membuat blog sehingga bertambahnya jumlah konsumen.

Ada enam cara yang bisa diterapkan untuk memaksimalkan penjualan bisnis layanan terapi home visit:

1. Memilih target pasar

2. Memilih media sosial sebagai sarana promosi

3. Menyediakan pelayanan prima

4. Menawarkan pembayaran melalui tansfer bank

5. Menawarkan promosi menarik

6. Membuat program loyalitas.

\section{DAFTAR PUSTAKA}

https://www.jurnal.id/id/blog/strategipraktis-pemasaran-jasa/

https://www.docdoc.com/id/info/specialty/t erapis-wicara/

http://www.idai.or.id/artikel/klinik/pengasu han-anak/mencegah-terlambat-bicarapada-anak

Kotler, dan Keller. (2012). Manajemen Pemasaran. Edisi 12. Jakarta: Erlangga.

Lupiyoadi, R. (2013). Manajemen Pemasaran Jasa: Berbasis Kompetensi Edisi 3. Jakarta: Penerbit Salemba. 